\title{
Management framework and practice of accounting theory
}

\author{
Peng Wang \\ Beijing Polytechnic College \\ Beijing 100042, China
}

\begin{abstract}
TIn this paper, with a theoretical framework for management accounting briefly reviewed, management accounting theory should make accounting environment and changing as the logical starting point and take objectives of management accounting as the core and take business management accounting information feedback mechanism as the link to the accounting information forecast to plan, implement control, performance evaluation and strategic decision management information systems.
\end{abstract}

Keywords- Management Accounting; logical starting point; nature; theoretical framework

\section{INTRODUCTION}

Management accounting and financial accounting are the two branches of the same accounting system, but the development of management accounting and is nowhere near the degree of attention and financial accounting. The current status of the development is the theory, which is mainly manifested in the management accounting has not yet been able to explain a complete guide and can be applied to the theoretical framework of management accounting practices, behind the practice. Whether Chinese or Western, management accounting research has always been emphasized on research methods, without attention to study the structure of the theory, such as the basic category management accounting objectives, assumptions, principles, methods and internal relations, so far few intensive systems research, making the management accounting hasn't yet formed a strict theoretical system. Due to the lack of solid theoretical foundation of management accounting, and the theory of long lack of theoretical guidance, this severely restricts the management accounting role to play. On the other hand, although the information theory, cybernetics, some behavioral science research systems, etc., have been introduced into the management accounting gradually, thus expanding the scope of management accounting, however, management accounting for from these different disciplines of science results, has not yet been able to fully and adequately digested, and people make a limited corrections to the management accounting just on the basis of these results on certain assumptions, and some still in the stage of qualitative analysis, but a lack of value.

\section{IDEOLOGICAL BASIS AND STAGE OF DEVELOPMENT OF A MANAGEMENT ACCOUNTING THEORY}

The generating of management accounting theory is inseparable from its environment, and management accounting environment in which generally refers to the generation, development and application of management accounting closely, and determine the aspects of management accounting ideas, theories, organization, discipline and regulations, such as the daily work objective historical conditions and the general term for special circumstances. Management accounting is being innovated and developed in the changing environment constantly, and management accounting theoretical framework research is inseparable from the study of economics and management theory of management accounting.

Origins of management Ideological in major economic management thinking of accounting management is rich, and many scholars have conducted extensive research, specifically summarized as follows: 1. The development of Taylor's scientific management theory, Frederick • Taylor is recognized as "scientific management father ", and his main point is to increase productivity by improving efficiency and to increase the wages of workers through the application of the scientific method. He emphasized the application of scientific principles to create a collective collaboration and cooperation to achieve the maximum output volume and capacity of workers. 2. Fayol theory of Development Administration, Henry Fayol • takes management as planning, organizing, directing, coordinating and controlling various functions, emphasizing scientific selection of workers as well as collaboration between workers and managers 3 . behavioral science theory, Hugo • Munsterberg used the psychology in industrial and management, Walter Scott - Deer - used the psychology in advertising, marketing and personnel management, studying influence degree of human psychological factors to work, seeking at what heart condition, in order to obtain the largest and most satisfactory output from each person's work. 4. Social systems theory, - Chester Barnard (1938) is analysis to mangers by using the method of management of a social system, focusing on the main factors of management aspects including extraordinary insights for decision-making and leadership, pointing out task managers in a formal organization to safeguard a collaborative system. 5. The decision theory, put forward by management scientists Herbert • A • Simon, his organizational decision theory has been successfully used to explain and predict all aspects of 
activity and Simon proposed decision theory of bounded rationality and satisfaction, organizational behavior and theory of individual decision-making, decision-making procedures and cognitive science, psychology of decisionmaking mechanisms. 6. Strategic Management, "Strategic Management" was first proposed in 1976 by the famous American scientist Ansoff management, strategic management is the business manager to develop strategies for the long-term goal of the enterprise on the basis of a comprehensive analysis of both inside and outside and control implementation process during the implementation process of the strategy 2 Problems of Theoretical Framework of Management Accounting in China

Accounting theory research and development is accompanied by the progressive development of human society, and there is agreement that is mainly due to the development of financial accounting. And their corresponding management accounting, due to its historical, social, cultural and other reasons, its development is relatively slow. Slow development of management accounting in the situation is particularly evident reason I believe that there are the following aspects: the seriously separation of management accounting theory and practice due to our management accounting theory mostly is following the Western theories, while China's economic conditions, environment, market and others have great differences from western countries but also the reality of China's environmental conditions and the presence of out of touch, resulting in many theories of management accounting in our country no way to get the application and promotion. In theory there is no formation suitable for China's management system on the status of management accounting theory of the present situation of China's accounting, and it mainly introduces the management accounting theory of West, without to digest and innovation entirely. Therefore, it does not form suitable for China's Management Accounting Theory in theory. And it does not reflect the strategic characteristics in terms of management accounting theory building and only fixes the original management accounting theory simplely, which is not suitable for the needs of the development of management accounting in the 21 st century. We pay less attention to our management accounting theory, all the time, have focused on the study of financial accounting theory and accounting standards, but pay little attention to management accounting. Therefore, it led management accounting to the theory seriously lagging behind objectively.

\section{CONSTRUCTION OF MANAGEMENT ACCOUNTING THEORY FRAMEWORK}

As previously mentioned analysis of the framework and researching of logical starting of management accounting theoretical framework refers to the management accounting theory and relations section of the components arranged between them and these elements form part of the interrelated but restrict mutual organic whole. So I believe that the management accounting theory framework should have the following salient features: First, the integrity.
Management accounting theory framework should be a whole that should provide a complete theory to explain all the problems in the field of management accounting, or at least all the major issues. Second, it is the contact ability. Between the various elements that constitute the theory of management accounting theory system is not scattered, isolated, unconnected, and disorderly pile or simple sequence list, but interrelated coordinated relationship with a certain logic, mutual restraint, promote each other, and there are other primary and secondary status and role of constituting a hierarchical, unified and indivisible systematic, whole. Third, it is the logic. Theory is "a systematic rational understanding," is characterized by systematic and coherent. American Accounting scientist Hendrickson believes in the "accounting theory" the accounting theory aims to provide the most important to evaluate and develop the around common viewpoint of accounting practices with consistent, rational principles. Scientific theoretical system must be to achieve seamless, consistent from beginning to end, from the premise, to assume all of the conclusions of the reasoning process and must strictly follow the basic principles of logic approaches. Therefore, within the management accounting concepts there is having deduced and strict logical relationship .Fourth, the hierarchy. Management Accounting Theory is a structured, clear functional system which can be divided from different angles. For example, some scholars divided accounting theory system into two basic theories -the basic and application theory; some scholars divided it into three levels: accounting research methods, basic accounting theory and accounting theory application; there are scholars divided it into four levels: accounting research methods, basic accounting theory, financial accounting conceptual structure, accounting theory application; etc. within each level, it also contains a number of specific accounting concepts, no matter how it be divided, it is undeniable with a hierarchical system. Fifth, it is dynamic. As the management accounting exists in a complex social and economic environment with diversity and hierarchy features, which makes management accounting theory system can not be absolute, unchanging, but is developing and changing. With the development of people's understanding of management accounting practice and socio-economic environment, the content of accounting theory system must also change in a sound continuous development accordingly. Dynamic of management accounting theory systems, does not mean that the theory can be subjectively and arbitrarily changes, it should be limited by social and historical conditions, and remained relative stable at a certain time. On the basis of assuring these features of management accounting theoretical framework, we then analyze the question of what is study of the theoretical framework logical starting point of management accounting is the starting point of management accounting constituting and the most abstract scope of this endogenous to account reasons of the theoretical framework of management and it is not only constitutes an integral part of the theoretical system, but is the decisive precondition theory to establish a theoretical framework for management accounting. I believe that taking the target and management accounting assumptions as the logical starting point for 
management accounting theoretical study has some shortcomings. Therefore, the logical starting point for management accounting theory system research should take development purposes research as starting point.

\section{USE STRATEGIC THINKING TO BUILD MANAGEMENT ACCOUNTING THEORY FRAMEWORK}

On core competence diagnosis and analysis, we should start from the external environment, but the cultivating and upgrade their core capabilities should proceed from the enterprise internal. Therefore, building a theoretical framework for the strategic management accounting must first analyze internal and external business environment. Through collecting internal and external information of business environment, and analyze and evaluate the collecting information, so that enterprises can be modified according to the information of the original development strategy, new development strategy, making the building of business development strategy on the scientific and reasonable basis and do basis for the enterprise investment, financing and dividend decisions. Second, build enterprise strategic management accounting theory framework must analyze enterprise value chain and cost drivers. Through analysis of the value chain, enterprise divides all of the business into value-added services and non-value added services, allowing companies to minimize non-value-added services, or even cancel the non-value-added activities, and promote economic efficiency of enterprises and maximize corporate value. Through the analysis of the enterprise cost drivers, it allows businesses to make cost drivers under control more or less, thus contribute to reduce costs and improve economic efficiency of enterprises. Finally, build enterprise strategic management accounting theory framework must develop a rational comprehensive enterprise performance evaluation system. Due to the traditional financial measures based performance evaluation system is being challenged.

The starting point analysis of the basic concepts is for management accounting framework. This paper argues that China's "management accounting basic conceptual framework" is consisted of the management accounting objectives, management accounting assumptions, the basic principles of management accounting, management accounting object elements and measurement and other elements. Within the constituent elements of the basic concepts of management accounting framework, it is not scattered, isolated, no contact, nor is disordered or simple list, but interrelated coordination, with some logic relationship and mutual restraint. To accurately describe the relationship in these elements and build management accounting basic structure of the conceptual framework, the first thing is determing the starting point of the frame. From the content point of the conceptual framework, there are two points: the existence of objectives starting and assumptions of management accounting. As a starting point of the basic concepts of management accounting framework should meet the following criteria: The most simple, basic accounting areas; able to contact the management accounting theory and management accounting practices; inherent, objective, making the basic concepts of management accounting framework has a relative stability and predictability. The assumption of management accounting management accounting is a basic prerequisite and constraints; however, it is not the most origin category. If we take management accounting assumptions as a logical starting point for the basic conceptual framework, although you can contact management accounting theory with practice of management accounting, management accounting assumptions can only come from the objective environment of management accounting and is restricted by subjective and objective factors. Obviously, the assumption of management accounting management accounting can not be as a starting point of basic conceptual framework, but only prerequisite concepts.

\section{CONCLUSIONS}

Management accounting theory is observing the phenomenon from the management accounting to its essence people on the basis of management accounting practice and summarized the scientific systematic conclusions of management accounting. It should be said the management accounting management accounting theory framework not includes various theoretical perspectives, but also the history of management accounting, management accounting research methods theory and ethics theory of management accounting professional and so on. Management Accounting basic conceptual framework is interlinked with logical and consistent system by the objectives of management accounting, management accounting objects, assumptions of management accounting, the basic principles of management accounting, to explain, evaluate, guide, develop and improve management accounting practices.

\section{References}

[1] Sun Jing. Corporate Environmental Cost Management Accounting Theory and Framework[D]. Inner Mongolia University, 2009.

[2] Jie maohua management framework and elements of accounting theory [J] Accounting Newsletter (Academic Edition), 2005,05: 1015.

[3] Wang Xin. Study behavior based on behavioral science of management accounting. Foreign Economic and Trade University, 2006

[4] Zhou Bingwei theoretical framework of management accounting in our country [J] Inner Mongolia Science Technology and Economy, 2008.12: 18-20.

[5] Feng Hung took the basic concept of our management accounting framework [J] Modern property (in Xunkan), 2009,12: 81-83.

[6] Zhang Lian government has the theoretical framework of strategic management accounting research $[\mathrm{J}]$ Chinese management information, 2011,02: 6-8.

[7] Liu Aidong, CAI Jian-ping management accounting theory framework [J] Contemporary Economic Management, 2007,01: 117120.

[8] Wang Mingfu theoretical framework of strategic management accounting research [J] Accounting Monthly, 2003.11: 7-8. 